\title{
IMPLEMENTASI PENEGAKAN SANKSI PIDANA TERHADAP KORPORASI YANG TIDAK MEMBAYAR DAN MENYETORKAN IURAN YANG MENJADI TANGGUNGJAWABNYA KEPADA BADAN PENYELENGGARA JAMINAN SOSIAL KETENAGAKERJAAN
}

Oleh :

\author{
Ardison Asri \\ Dosen Tetap Fakultas Hukum Universitas Dirgantara Marsekal Suryadarma Jakarta. \\ Email : Ardison3077@gmail.com
}

\begin{abstract}
Abstrak
Persoalan mendasar berkenaan dengan penelitian ini adalah bagaimana pertanggungjawaban pidana terhadap korporasi yang tidak membayar dan menyetorkan iuran yang menjadi tanggungjawabnya kepada Badan Penyelenggara Jaminan Sosial Ketenagakerjaan dan proses penegakan sanksi pidana terhadap korporasi tersebut. Penelitian ini menggunakan metode penelitian hukum yuridis normatif, terutama dengan melakukan analisis terhadap implementasi penegakan sanksi pidana terhadap korporasi yang melakukan tindak pidana dalam Undang-Undang Nomor 24 Tahun 2011 tentang Badan Penyelenggara Jaminan Sosial. Hasil penelitian ini menunjukan bahwa baik sebagai subjek hukum maupun perbuatan atas pelanggaran korporasi yang tidak membayar dan menyetorkan iuran yang menjadi tanggungjawabnya kepada Badan Penyelenggara Jaminan Sosial Ketenagakerjaan dapat dimintai pertanggungjawaban pidananya.
\end{abstract}

Kata Kunci : Implementasi, penegakan sanksi pidana, korporasi, Badan Penyelenggara Jaminan Sosial Ketenagakerjaan.

\section{PENDAHULUAN}

Bahwa tujuan dibentuknya suatu aturan adalah untuk mengatur tatanan hidup masyarakat, sehingga aturan das sollen harus diimbangi dengan penerapan das sein di lapangan. Begitu juga mengenai pengaturan hak dan kewajiban semuanya diatur dan ditentukan oleh aturan hukum. ${ }^{1}$ Demikian juga alasan kenapa dalam hukum perburuhan/ketenagakerjaan campur tangan pemerintah (penguasa)

${ }^{1}$ Ishaq, Dasar-dasar Ilmu Hukum, Sinar Grafika, Jakarta, 2009, hlm. 77. diperlukan. Bisa kita bayangkan, jika hubungan antara pekerja dengan pengusaha yang secara sosial ekonomi sangat berbeda namun semuanya diserahkan kepada para pihak, tentu tujuan untuk menciptakan keadilan dalam hubungan perburuhan/ketenagakerjaan akan sulit tercapai, karena yang kuat akan selalu ingin menguasai yang lemah. Atas dasar itulah pemerintah perlu turut campur tangan dalam pelaksanaan hubungan perburuhan / ketenagakerjaan melalui peraturan perundang - undangan guna memberikan jaminan kepastian 
pelaksanaan hak dan kewajiban para pihak dalam konsep hubungan industrial. ${ }^{2}$

Dalam konsep hubungan industrial, antara hak dan kewajiban sudah diatur sedemikian rupa dalam peraturan perundang-undangan yang berlaku. Salah satu yang diatur dalam pelaksanaan hak dan kewajiban ketenagakerjaan adalah melalui jaminan sosial ketenagakerjaan yang diatur melalui Undang-Undang Nomor 24 Tahun 2011 tentang Badan Penyelenggara Jaminan Sosial.

Dalam Undang-Undang Nomor 24 Tahun 2011 tentang Badan Penyelenggara Jaminan Sosial, disamping mengatur program jaminan kesehatan yang diselenggarakan oleh Badan Penyelenggara Jaminan Sosial (BPJS) Kesehatan juga mengatur tentang jaminan ketenagakerjaan yang diselenggarakan oleh Badan Penyelenggara Jaminan Sosial (BPJS) Ketenagakerjaan.

Adapun program jaminan ketenagakerjaan yang diatur dalam Undang-undang tersebut adalah Jaminan Kecelakaan Kerja (JKK), Jaminan Kematian (JK), Jaminan Hari Tua (JHT) dan satu lagi tambahan yaitu Jaminan Pensiun (JP). Artinya, BPJS Ketenagakerjaan inilah yang akan melaksanakan tugas dan fungsinya sebagai penyelenggara jaminan sosial yang erat kaitannya dengan para Pekerja dan Pemberi Kerja ataupun Korporasi. Hal ini terlihat dalam hubungan yang berkaitan dengan iuran yang nantinya harus dibayarkan oleh pihak korporasi guna menjamin para pekerjanya mendapatkan program jaminan sosial yang diselengggarakan oleh BPJS Ketenagakerjaan.

\footnotetext{
${ }^{2}$ Lalu Husni, Hukum Ketenagakerjaan Indonesia, Rajawali Pers, Jakarta, 2010, hlm. 57.
}

Pasal 19 Undang-Undang Nomor 24 Tahun 2011 tentang Badan Penyelenggara Jaminan Sosial, menyebutkan:

Pasal 19 ayat (1) : "Pemberi Kerja wajib
memungut Iuran
yang menjadi beban
Pesertar dari
Pekerjanya dan
menyetorkannya
kepada BPJS".

Pasal 19 ayat (2) : "Pemberi Kerja wajib membayar dan menyetorkannya Iuran yang menjadi tanggungjawabnya kepada BPJS". ${ }^{3}$

Pelanggaran atas ketentuan Pasal 19 ayat (1) dan ayat (2) tersebut di atas, diatur lebih lanjut dalam Pasal 55 UndangUndang Nomor 24 Tahun 2011 tentang Badan Penyelenggara Jaminan Sosial, yang menyebutkan bahwa :

"Pemberi Kerja yang melanggar ketentuan sebagaimana diatur dalam Pasal 19 ayat (1) dan ayat (2) dipidana dengan pidana penjara paling lama 8 (delapan) tahun atau denda paling banyak Rp. 1.000.000.000,- (satu miliar Rupiah)".

Dari ketentuan pasal-pasal tersebut di atas, artinya Undang-Undang Nomor 24 Tahun 2011 tentang Badan Penyelenggara Jaminan Sosial dapat meminta pertanggungjawaban pidana atau dapat dikenakannya sanksi pidana terhadap korporasi. Dengan begitu, ketika sistem hukum pidana Indonesia mengakui eksistensi korporasi sebagai subjek hukum dalam hukum pidana terutama yang

${ }^{3}$ Fokusindo Mandiri, Sistem Jaminan Sosial Nasional \& Badan Penyelenggara Jaminan Sosial, Bandung, 2014, hlm. 45. 
terdapat dalam perundang-undangan pidana di luar Kitab Undang-undang Hukum Pidana (KUHP) baik yang berbentuk Undang-undang pidana khusus maupun Undang-undang pidana administrasi, kondisi demikian memiliki implikasi hukum yang tidak sederhana terhadap 3 (tiga) konsep dasar dalam ilmu hukum pidana, yaitu tindak pidana, pertanggungjawaban pidana serta pidana atau pemidanaan.

Suatu korporasi dikatakan melakukan suatu perbuatan yang dilarang tentu saja kerangka teoritisnya berbeda dengan tindak pidana yang dilakukan oleh manusia. Demikian juga dengan penentuan pertanggungjawaban pidana, format kesalahan dan kemampuan bertanggungjawabnya korporasi. Hal ini karena sifat dan karakteristik yang melekat pada korporasi ketika melakukan suatu perbuatan pada dasarnya berbeda dengan sifat dan karakteristik yang ada pada diri manusia. ${ }^{4}$

Berdasarkan ketentuan Pasal 55 Undang-Undang Nomor 24 Tahun 2011 tentang Badan Penyelenggara Jaminan Sosial dan eksistensi korporasi sebagai subjek hukum dalam hukum pidana terutama yang terdapat dalam perundangundangan pidana di luar KUHP, baik yang berbentuk Undang-undang pidana khusus maupun Undang-undang pidana administrasi, tentu hal ini menarik untuk dikaji dalam penulisan jurnal ilmiah hukum dengan judul "Implementasi Penegakan Sanksi Pidana Terhadap Korporasi yang Tidak Membayar dan Menyetorkan Iuran yang Menjadi Tanggungjawabnya Kepada Badan Penyelenggara Jaminan Sosial Ketenagakerjaan".

\footnotetext{
${ }^{4}$ Mahrus Ali, Asas-Asas Hukum Pidana Korporasi, PT
} Raja Grafindo Persada, Jakarta, 2015, hlm. vii-viii.
Karena itu, ruang lingkup masalah yang akan dikaji dalam suatu analisis penulisan ini adalah: (1) Bagaimana pertanggungjawaban pidana terhadap korporasi yang tidak membayar dan menyetorkan iuran yang menjadi tanggungjawabnya kepada Badan Penyelenggara Jaminan Sosial Ketenagakerjaan? dan (2) Bagaimana proses penegakan sanksi pidana terhadap korporasi yang tidak membayar dan menyetorkan iuran yang menjadi tanggungjawabnya kepada Badan Penyelenggara Jaminan Sosial Ketenagakerjaan?

\section{METODE PENELITIAN}

Sehubungan ruang lingkup
permasalahan yang dibahas dalam implementasi penegakan sanksi pidana terhadap korporasi yang tidak membayar dan menyetorkan iuran yang menjadi tanggungjawabnya kepada Badan Penyelenggara Jaminan Sosial Ketenagakerjaan, maka metode penelitiannya adalah metode penelitian hukum yuridis normatif, dimana dalam penelitian ini melakukan penelusuran terhadap norma-norma hukum yang terdapat dalam peraturan-peraturan mengenai implementasi penegakan sanksi pidana terhadap korporasi yang melakukan tindak pidana dalam UndangUndang Nomor 24 Tahun 2011 tentang Badan Penyelenggara Jaminan Sosial. Disamping itu, metode ini juga memperhatikan literatur perpustakaan, jurnal dan lain sebagainya.

Sementara metode pendekatan yang dilakukan dalam penulisan ini adalah pendekatan perundang-undangan (statute approach) dengan sifat penelitian yang dipergunakan adalah menggunakan metode penelitian deskriptif yang 
bertujuan menggambarkan keadaan objek atau masalah tanpa maksud untuk mengambil kesimpulan-kesimpulan yang berlaku secara umum.

Sedangkan teknik pengumpulan datanya adalah melalui studi kepustakaan (library research) yang kemudian dianalisis dengan menggunakan analisis deskriptif kualitatif.

\section{PEMBAHASAN}

\section{Pertanggungjawaban Pidana Terhadap Korporasi yang Tidak Membayar dan Menyetorkan Iuran yang Menjadi Tanggungjawabnya Kepada Badan Penyelenggara Jaminan Sosial Ketenagakerjaan}

Sebelum membahas pertanggungjawaban pidana korporasi, mungkin perlu dijelaskan terlebih dahulu apakah UndangUndang Nomor 24 Tahun 2011 tentang Badan Penyelenggara Jaminan Sosial mengatur tentang kewajiban dan pertanggungjawaban pidana korporasi tersebut? Pasal 1 angka 9 Undang-Undang Nomor 24 Tahun 2011 tentang Badan Penyelenggara Jaminan Sosial, menjelaskan bahwa:

"Pemberi Kerja adalah orang
perseorangan, pengusaha, badan
hukum, atau badan lainnya yang
mempekerjakan tenaga kerja atau
penyelenggara negara yang
mempekerjakan pegawai negeri
dengan membayar gaji, upah, atau
imbalan dalam bentuk lainnya".

Sementara menurut Muladi dan Dwidja Priyatno, korporasi yang dalam Bahasa Inggris disebut legal entities atau corporation merupakan sebutan yang lazim digunakan di kalangan ahli ilmu hukum perdata sebagai badan hukum. ${ }^{5}$ Sebagai salah satu subjek hukum selain manusia, maka korporasi sebagai badan hukum dapat dimintai pertanggungjawabannya secara hukum baik perdata maupun pidana atas pelaksanaan hak dan kewajibannya.

Ketentuan mengenai kewajiban korporasi untuk melakukan pembayaran iuran kepada Badan Penyelenggara Jaminan Sosial dalam Undang-Undang Nomor 24 Tahun 2011 tentang Badan Penyelenggara Jaminan Sosial diatur dalam Pasal 19 ayat (1) dan ayat (2), yang menyebutkan :

Pasal 19 ayat (1) : "Pemberi Kerja wajib memungut Iuran yang menjadi beban Peserta dari Pekerjanya dan menyetorkannya kepada BPJS".

Pasal 19 ayat (2) : "Pemberi Kerja wajib membayar dan menyetorkannya Iuran yang menjadi tanggungjawabnya kepada BPJS".

Pelanggaran atas ketentuan Pasal 19 ayat (1) dan ayat (2) di atas diatur lebih lanjut dalam Pasal 55 Undang-Undang Nomor 24 Tahun 2011 tentang Badan Penyelenggara Jaminan Sosial, yang menyebutkan bahwa:

"Pemberi Kerja yang melanggar ketentuan sebagaimana diatur dalam Pasal 19 ayat (1) dan ayat (2) dipidana dengan pidana penjara paling lama 8 (delapan) tahun atau denda paling banyak Rp. 1.000.000.000,- (satu miliar Rupiah)".

${ }^{5}$ Muladi dan Dwidja Priyatno, Pertanggungjawaban Pidana Korporasi dalam Hukum Pidana, STIH, Bandung, 1991, hlm. 19-20. 
Artinya, dari ketentuan Pasal 55 tersebut di atas, pertanggungjawaban pidana terhadap korporasi yang tidak membayar dan menyetorkan iuran yang menjadi tanggungjawabnya kepada Badan Penyelenggara Jaminan Sosial Ketenagakerjaan dapat dimintai dengan pertimbangan, sebagai berikut :

\section{Konsep Kesalahan dan Fungsinya}

Adagium "tiada pidana tanpa kesalahan" (geen straf zonder schuld) dalam hukum pidana lazimnya dipakai dalam arti tiada pidana tanpa kesalahan subjektif atau kesalahan tanpa dapat dicela. Akan tetapi dalam hukum pidana, orang tidak dapat berbicara tentang kesalahan tanpa adanya perbuatan yang tidak patut. Karena itu asas kesalahan diartikan sebagai tiada pidana tanpa perbuatan tidak patut yang objektif, yang dapat dicelakan kepada pelakunya. Asas kesalahan merupakan asas yang fundamental dalam hukum pidana, demikian fundamentalnya sehingga meresap dan menggema dalam hampir semua ajaran dalam hukum pidana. ${ }^{6}$

Karena kesalahan merupakan asas yang fundamental dalam hukum pidana, wajar bila Remmelink menyatakan bahwa:

Bagaimanapun juga, kita tidak rela membebankan derita kepada orang lain, sekedar karena orang itu melakukan tindak pidana, kecuali kita yakin bahwa ia memang dapat dipersalahkan karena tindakannya itu. Karena itu, dapat juga diandaikan bahwa manusia dalam kondisi yang tidak terlalu abnormal,

${ }^{6}$ Muladi dan Dwidja Priyatno, Pertanggungjawaban Pidana Korporasi, Cet. Kedua, Prenada Media, Jakarta, 2010, hlm. 99 -100. sepanjang ia memang menginginkannya, muncul sebagai makhluk yang memiliki akal budi serta sanggup dan mampu menaati norma-norma masuk akal yang ditetapkan oleh masyarakat sebagai jaminan kehidupannya. Karena itu kesalahan adalah pencelaan yang ditujukan oleh masyarakat yang menerapkan standar etis yang berlaku pada waktu tertentu terhadap manusia yang melakukan perilaku menyimpang yang sebenarnya dapat dihindari. ${ }^{7}$

Terkait dengan adagium tiada pidana tanpa kesalahan, E.Ph. Sutorious menyatakan bahwa, pertamatama harus diperhatikan bahwa kesalahan selalu hanya mengenai perbuatan yang tidak patut, yaitu melakukan sesuatu yang seharusnya tidak dilakukan dan tidak melakukan sesuatu yang seharusnya dilakukan. Ditinjau secara lebih mendalam, kesalahan memandang hubungan antara perbuatan tidak patut dan pelakunya sedemikian rupa sehingga perbuatan itu dalam arti kata yang sesungguhnya merupakan perbuatannya. Perbuatan itu tidak hanya objektif tidak patut, tetapi juga dapat dicelakan kepadanya. Dapat dicelakan itu bukanlah merupakan inti dari pengertian kesalahan, tetapi akibat dari kesalahan. Sebab hubungan antara perbuatan dan pelakunya itu selalu membawa pencelaan, maka orang

\footnotetext{
7 Remmelink, Hukum Pidana Komentar atas Pasalpasal Terpenting dari Kitab Undang-undang Hukum Pidana Belanda dan Padanannya dalam Kitab Undangundang Hukum Pidana Indonesia, Diterjemahkan oleh Tristam Pascal Moeliono, PT Gramedia Pustaka Utama, Jakarta, 2003, hlm. 142.
} 
menamakan sebagai dapat dicela. Oleh karena itu, asas tiada pidana tanpa kesalahan mempunyai arti bahwa agar dapat menjatuhkan pidana, tidak hanya disyaratkan bahwa seseorang telah berbuat tidak patut secara objektif, tetapi juga bahwa perbuatan tidak patut itu dapat dicelakan kepadanya. ${ }^{8}$

Uraian dari E.Ph. Sutorius itu sesungguhnya memiliki substansi yang sama dengan yang dikemukakan Remmelink, yakni kesalahan terkait dengan perbuatan pelaku yang tidak patut. Namun demikian, baik penjelasan Remmelink maupun Sutorious mengenai kesalahan pada dasarnya tidak memberikan arti dari kesalahan itu sendiri. Lalu, apa makna kesalahan dalam hukum pidana? Para ahli hukum pidana mengartikan kesalahan secara beragam, tapi secara umum pengertian yang dikemukakan mengarah pada 2 (dua) macam, yaitu kesalahan psikologis dan kesalahan normatif.

Kesalahan psikologis adalah keadaan batin (psychis) yang tertentu dari sipembuat dan hubungan antara keadaan batin tersebut dengan perbuatannya sedemikian rupa, sehingga pembuat dapat dipertanggungjawabkan atas perbuatannya itu. ${ }^{9}$ Konsep kesalahan psikologis yang menitikberatkan pada keadan batin tentu bersifat subjektif, dalam arti indikator keadaan batin seseorang dengan keadaan batin orang lain tidak sama. Karena itulah, konsep kesalahan psikologis tidak banyak diikuti karena menimbulkan persoalan

8 E.Ph. Sutorious dalam Muladi dan Dwidja Priyatno, Pertanggungjawaban Pidana Korporasi, Cet. Kedua, Prenada Media, Jakarta, 2010, hlm. 100101.

9 Tongat, Dasar-dasar Hukum Pidana Indonesia dalam Perspektif Pembaharuan, UMM Press, Malang, 2008, hlm. 222. dalam praktik hukum yang dipicu oleh ketiadaan unsur "dengan sengaja" atau "karena kealpaan" dalam rumusan tindak pidana. Dalam Kitab Undangundang Hukum Pidana yang berlaku saat ini, tindak pidana pelanggaran tidak memuat unsur "dengan sengaja" atau "karena kealpaan". Oleh karena itu, praktik hukum sempat diliputi pertanyaan sekitar apakah tidak dirumuskannya unsur "dengan sengaja" atau "karena kealpaan" dalam pelanggaran menyebabkan pembuatnya tetap dipidana, sekalipun tidak ada salah satu dari kedua bentuk kesalahan tersebut. Persoalan ini timbul dan menyebabkan adanya keragu-raguan atas kemampuan teori kesalahan psikologis untuk menjelaskan masalah kesalahan. $^{10}$

Persoalan itulah yang menyebabkan mengapa teori kesalahan normatif dijadikan dasar untuk menentukan masalah kesalahan. Menurut kesalahan normatif, kesalahan diartikan sebagai dapat dicelanya pembuat tindak pidana karena dilihat dari segi masyarakat sebenarnya dia dapat berbuat lain jika tidak ingin melakukan perbuatan tersebut. ${ }^{11}$ Orang dapat dikatakan mempunyai kesalahan, jika dia pada waktu melakukan tindak pidana, dilihat dari segi masyarakat dapat dicela karenanya, yaitu kenapa melakukan perbuatan yang merugikan masyarakat padahal mampu untuk mengetahui makna perbuatan tersebut, dan

\footnotetext{
${ }^{10}$ Chairul Huda, Dari Tiada Pidana Tanpa Kesalahan Menuju Kepada Tiada Pertanggungjawaban Pidana Tanpa Kesalahan, Cet. Kedua, Kencana, Jakarta, 2006, hlm. 73.

11 Roeslan Saleh, Tindak Pidana dan Pertanggungjawaban Pidana; Dua Pengertian Dasar dalam Hukum Pidana, Cetakan Ketiga, Aksara Baru, Jakarta, 1983, hlm. 77.
} 
Implementasi Penegakan Sanksi Pidana Terhadap Korporasi Yang Tidak

Membayar Dan Menyetorkan Iuran Yang Menjadi Tanggungjawabnya

Kepada Badan Penyelenggara Jaminan Sosial Ketenagakerjaan

karenanya dapat bahkan harus menghindari perbuatan demikian. ${ }^{12}$

2. Kesalahan sebagai Syarat Penjatuhan Pidana

Ketika dijelaskan bahwa adagium "tiada pidana tanpa kesalahan" merupakan asas yang sangat penting dan berpengaruh dalam hukum pidana, maka terdapat 2 (dua) hal penting yang perlu dikemukakan. Pertama, kita baru berbicara tentang kesalahan, manakala perbincangan tentang tindak pidana sudah selesai. Artinya, ahli hukum pidana ataupun hakim baru bisa menilai kesalahan yang ada pada diri seseorang bila orang tersebut telah terbukti melakukan suatu perbuatan yang dilarang. Hal ni karena pengertian kesalahan didalamnya tidak termasuk pengertian tindak pidana, kecuali kita mengikuti monisme, suatu teori yang menggabungkan aspek perbuatan dan kesalahan pelaku ke dalam pengertian tindak pidana. Pengertian tindak pidana oleh simons sebagai "suatu tindakan melanggar hukum yang telah dilakukan dengan sengaja ataupun tidak dengan sengaja oleh seseorang yang dapat dipertanggungjawabkan atas tindakannya dan yang oleh Undangundang telah dinyatakan sebagai suatu tindakan yang dapat dihukum", ${ }^{13}$ pada dasarnya merupakan contoh dari tidak dipisahkannya aspek perbuatan pelaku dan kesalahan dirinya.

Kedua, sanksi pidana (punishment) atau sanksi tindakan (treatment) hanya dapat dijatuhkan oleh hakim kepada seseorang yang terbukti melakukan perbuatan yang dilarang atau

12 Moeljatno, Asas-asas Hukum Pidana, Cet. Kedelapan, Rineka Cipta, Jakarta, 2008, hlm. 169.

13 P.A.F Lamintang, Dasar-dasar Hukum Pidana Indonesia, Cet. Ketiga, PT. Citab Aditya Bakti, Bandung, 1997, hlm. 185 mengabaikan kewajiban hukum untuk bertindak, jika pada diri orang tersebut terdapat kesalahan. Ini artinya, kesalahan menjadi syarat penentu penjatuhan pidana. Penjatuhan pidana menjadi sah dan mendapatkan pembenaran secara teoritis bila pada orang yang dijatuhkan pidana tersebut terdapat kesalahan, baik dalam bentuk kesengajaan ataupun kealpaan. Dengan demikian, pada aspek yang kedua ini, adagium "tiada pidana tanpa kesalahan" diartikan sebagai berikut : hakim hanya sah menjatuhkan pidana kepada terdakwa jika pada dirinya terdapat kesalahan serta tidak ada alasan yang memafkan kesalahannya itu.

\section{Kesengajaan dan Kealpaan}

Secara teoritis terdapat 2 (dua) bentuk kesengajaan (dolus) yaitu dolus malus dan dolus eventualis. Dolus malus hakikatnya merupakan inti dari gabungan dari teori pengetahuan (voorstelling theorie) dan teori kehendak (wilsttheorie). Menurut teori pengetahuan seseorang sudah dapat dikatakan sengaja melakukan tindak pidana jika saat berbuat orang tersebut mengetahui atau menyadari bahwa perbuatannya itu merupakan perbuatan yang dilarang oleh hukum. ${ }^{14}$ Teori ini menitikberatkan pada saat melakukan tindak pidana. ${ }^{15}$ Sedangkan teori kehendak menyatakan, bahwa seseorang dianggap sengaja melakukan suatu tindak pidana apabila orang itu menghendaki dilakukannya perbuatan itu. Dalam konteks ini, kesengajaan

\footnotetext{
${ }^{14}$ M. Abdul Kholiq, Buku Pedoman Kuliah Hukum Pidana, Fakultas Hukum Universitas Islam Indonesia, Yogyakarta, 2002, hlm. 133.

15 Sudarto, Diktat Kuliah Hukum Pidana Jilid A-B, Faku ltas Hukum Unives itas Diponegoro, Semarang, 1975, hlm. 16.
} 
merupakan kehendak yang diarahkan pada terwujudnya perbuatan seperti yang dirumuskan dalam Undangundang. ${ }^{16}$

Dolus eventualis adalah sengaja yang bersifat kemungkinan. Di katakan demikian, karena pelaku yang bersangkutan pada waktu ia melakukan perbuatan untuk menimbulkan suatu akibat yang dilarang oleh Undangundang telah menyadari kemungkinan akan timbulnya suatu akibat lain dari akibat yang memang ia kehendaki. Jika kemungkinan yang ia sadari itu kemudian menjadi kenyataan, terhadap kenyataan tersebut ia katakan mempunyai kesengajaan. ${ }^{17}$

Van Bemmelan mengatakan bahwa yang dinamakan dolus ventualis adalah kesengajaan bersyarat yang bertolak dari kemungkinan, dalam arti tidak pernah lebih banyak dikehendaki kemungkinan matinya orang lain itu misalnya. Seseorang yang menghendaki kemungkinan matinya orang lain, tidak dapat dikatakan bahwa ia menghendaki supaya orang itu mati. Tetapi, jika seseorang melakukan suatu perbuatan dengan kesadaran bahwa perbuatannya akan dapat menyebabkan matinya orang lain, hal itu menunjukkan bahwa ia memang menghendaki kematian orang itu. ${ }^{18}$

Berdasarkan uraian mengenai dolus eventualis di atas dapat disimpulkan bahwa pelaku tindak pidana menyadari bahwa perbuatannya itu sangat mungkin akan menimbulkan terjadinya akibat tertentu yang dilarang hukum. Namun, meskipun ia menyadari hal itu, sikap yang muncul pada dirinya

${ }^{16}$ Moeljatno, Op. cit, hlm. 186.

${ }^{17}$ P.A.F Lamintang, Op. cit, hlm. 301.

18 Leden Marpaung, Asas-Teori-Praktik Hukum Pidana, Cet. Kedua, Sinar Grafika, Jakarta, 2005, hlm. 18. bukannya menjauhi perbuatan itu, melainkan justru tetap melakukannya dengan berpandangan bahwa kalaupun akibat tertentu yang dilarang akan terjadi, ya apa boleh buat. Dalam hubungan inilah, dolus eventualis juga disebut dengan inklauf nehmen theorie atau teori apa boleh buat. ${ }^{19}$

Adapun kealpaan, Kitab Undangundang Hukum Pidana tidak memberikan penjelasan tentang pengertian kealpaan (culps), sehingga secara formal tidak ada penjelasan mengenai apa yang dimaksud dengan kealpaan. Oleh karenanya, pengertian kealpaan harus dicari di dalam pendapat para ahli hukum pidana dan dijadikan sebagai dasar untuk membatasi apa itu kealpaan.

Terdapat beberapa istilah yang digunakan untuk pada kata "kealpaan", seperti recklessness, negligence, sembrono, dan teledor. $^{20}$ Simons mengatakan bahwa umumnya kealpaan itu terdiri atas 2 (dua) bagian, yaitu tidak berhatihati melakukan suatu perbuatan, disamping dapat menduga akibatnya. Namun, meskipun suatu perbuatan dilakukan dengan hati-hati, masih mungkin juga terjadi kealpaan yang berbuat itu telah mengetahui bahwa dari perbuatan itu mungkin akan timbul suatu akibat yang dilarang Undangundang. Kealpaan terjadi apabila seseorang tetap melakukan perbuatan itu meskipun ia telah mengetahui atau menduga akibatnya. Dapat diduganya akibat itu lebih dahulu oleh pelaku adalah suatu syarat mutlak. Suatu akibat yang tidak dapat diduga lebih dahulu tidak dapat

19 Tongat, Op. cit, hlm. 247.

${ }^{20} \mathrm{Ibid}, \mathrm{hlm} .276$. 
dipertanggungjawabkan kepadanya sebagai kealpaan. ${ }^{21}$

Moeljatno mengatakan bahwa kealpaan adalah suatu struktur yang sangat gecompliceerd, yang disatu sisi mengarah pada kekeliruan dalam perbuatan seseorang secara lahiriah, dan disisi lain mengarah pada keadaan batin orang itu. Dengan pengertian demikian, maka di dalam kealpaan (culpa) terkandung makna kesalahan dalam arti luas yang bukan berupa kesengajaan. Terdapat perbedaan antara kesengajaan dan kealpaan, di mana dalam kesengajaan terdapat suatu sifat positif, yaitu adanya kehendak dan persetujuan pelaku untuk melakukan suatu perbuatan yang dilarang. Sedangkan dalam kealpaan sifat positif ini tidak ditemukan. ${ }^{22}$

\section{Menentukan Kesalahan Korporasi}

Dikarenakan korporasi tidak dapat melakukan tindak pidana tanpa melalui perantara pengurusnya, maka penentuan kesalahan korporasi adalah dengan melihat apakah pengurus, yang bertindak untuk dan atas nama korporasi memiliki kesalahan. Jika jawabannya adalah iya, maka korporasi dinyatakan bersalah atas tindak pidana yang dilakukannya. Demikian juga sebaliknya. Mardjono Reksodiputro menyatakan bahwa kesalahan yang ada pada diri pengurus korporasi dialihkan atau menjadi kesalahan korporasi itu sendiri. ${ }^{23}$

Walaupun kesalahan pengurus korporasi dialihkan dan menjadi kesalahan korporasi, isi kesalahan tersebut berbeda dengan kesalahan pada

${ }^{21}$ Leden Marpaung, Op. cit., hlm. 25.

${ }^{22}$ Moeljatno, Op. cit., hlm. 217.

${ }^{23}$ Mahrus Ali, Asas-Asas Hukum Pidana Korporasi, PT

Raja Grafindo Persada, Jakarta, 2015, hlm. 152. subjek hukum manusia. Dasar dari penetapan dipersalahkannya korporasi ialah tidak dipenuhinya dengan baik fungsi kemasyarakatan yang dimiliki korporasi. Dilihat dari segi masyarakat korporasi telah tidak menjalankan fungsinya dengan baik. Indikator kesalahan bagi korporasi adalah bagaimana korporasi menjalankan fungsi kemasyarakatannya itu. Fungsi kemasyarakatan itu termasuk tetapi tidak terbatas untuk menghindari terjadinya tindak pidana. Dengan demikian, hukum mengharapkan kepada korporasi untuk menjalankan fungsi kemasyarakatannya dengan baik sehingga sejauh mungkin dapat menghindari terjadinya tindak pidana. Dengan kata lain, selagi terbuka kemungkinan bagi korporasi untuk "dapat berbuat lain" selain melakukan tindak pidana, maka harapan tersebut harus sejauh mungkin tercermin dari kebijakan dan pengoperasiannya. Terhadap korporasi penilaian adanya kesalahan ditentukan oleh bagaimana korporasi memenuhi fungsi kemasyarakatannya, sehingga "dapat dicela" ketika suatu tindak pidana terjadi karenanya. ${ }^{24}$

Dalam kepustakaan syarat kesalahan pada korporasi disebut dengan syarat kekuasaan (machtsvereiste). Muladi mengatakan sebagai berikut :

Syarat kekuasaan mencakup : wewenang mengatur / menguasai dan / atau memerintah pihak yang dalam kenyataannya melakukan tindakan terlarang tersebut; mampu melaksanakan kewenangannya dan pada dasarnya mampu mengambil keputusan-keputusan tentang

\footnotetext{
${ }^{24}$ Ibid., hlm. 153.
} 
hal yang bersangkutan; dan mampu mengupayakan kebijakan atau tindakan pengamanan dalam rangka mencegah dilakukannya tindakan terlarang. ${ }^{25}$

Sedangkan menurut Muladi, syarat kesalahan korporasi hanya berkenaan dengan mampu mengupayakan kebijakan atau tindakan pengamanan dalam rangka mencegah dilakukannya tindakan terlarang. ${ }^{26}$

Hubungan antara kesalahan korporasi dan syarat-syaratnya dengan teori-teori tentang pertanggungjawaban pidana korporasi pembuktiannya yaitu terlihat pada teori direct corporate criminal liability kesalahan pengurus korporasi yang bertindak untuk dan/atau atas nama korporasi mutlak diperlukan dan harus dibuktikan. Walaupun pengurus tersebut terbukti melakukan suatu perbuatan yang dilarang pada dirinya harus juga dibuktikan adanya kesalahan, sehingga pidana yang dijatuhkan baik kepada pengurus maupun kepada korporasi memiliki justifikasi teoritis yang memadai. Dengan kata lain, perlu dibuktikan tidak hanya bahwa pengurus telah melakukan tindak pidana, tapi juga terdapat kesalahan pada dirinya, dimana kesalahan tersebut secara otomatis menjadi kesalahan korporasi.

Pada teori strict liability, eksistensi kesalahan korporasi tetap diperlukan walaupun tidak perlu dibuktikan. Premis utama teori strict liability, yakni liability without fault tidak kemudian dimaknai bahwa pada teori tersebut kesalahan korporasi tidak perlu ada,

25 Muladi, Demokratisasi, Hak Asasi Manusia dan Reformasi Hukum di Indonesia, The Habibie Center, Jakarta, 2002, hlm. 160 -161.

${ }^{26}$ Chairul Huda, Op.cit., hlm. 101-102. tapi hendaknya pemaknaan teori tersebut lebih kepada tidak perlunya pembuktian unsur kesalahan pada korporasi. Terbuktinya unsur tindak pidana sudah cukup bagi hakim untuk menjatuhkan pidana kepada korporasi, tanpa perlu dibuktikan unsur kesalahannya, karena bila kesalahan tidak diperlukan, hal demikian sama saja dengan melabrak asas "tiada pidana tanpa kesalahan". Cella Wells sebagaimana dikutip oleh Yusuf Shofie menyatakan sebagai berikut : "..... that a culpability elemen such as intention, recklessness, or negligence need not to be proved". ${ }^{27}$

Kaitan antara penentuan kesalahan suatu korporasi dengan tindak pidana dalam Undang-Undang Nomor 24 Tahun 2011 yaitu perihal subjek dan perbuatan. Perihal subjek bahwa korporasi itu merupakan badan hukum, dan badan hukum merupakan bagian atau termasuk kedalam kategori "Pemberi Kerja" yang diatur dalam Ketentuan Umum dalam UndangUndang Nomor 24 Tahun 2011 tentang Badan Penyelenggara Jaminan Sosial. Artinya, bahwa korporasi merupakan subjek yang dapat mempertanggungjawabkan perbuatan pidana yang dilakukannya ketika melanggar ketentuan dalam UndangUndang Nomor 24 Tahun 2011 tentang Badan Penyelenggara Jaminan Sosial dan dalam hal ini direksi dari korporasi/perusahaan yang melanggar ketentuan Undang-Undang Nomor 24 Tahun 2011 tentang Badan Penyelenggara Jaminan Sosial yang akan mewakili korporasi dalam hal terjadinya tindak pidana dalam proses persidangan di pengadilan.

\footnotetext{
${ }^{27}$ Mahrus Ali, Op. cit., hlm. 155.
} 
Kemudian perihal perbuatannya, menurut hemat penulis bahwa Pemberi Kerja wajib memungut Iuran yang menjadi beban Peserta dari Pekerjanya dan menyetorkannya kepada Badan Penyelenggara Jaminan Sosial Ketenagakerjaan dan Pemberi Kerja wajib membayar dan menyetor Iuran yang menjadi tanggung jawabnya kepada Badan Penyelenggara Jaminan Sosial Ketenagakerjaan. Jika Pemberi Kerja tidak melakukan hal sebagaimana tersebut di atas baik secara sengaja maupun lalai (dolus atau culpa), maka Pemberi kerja atau korporasi telah melakukan kesalahan sebagai syarat penjatuhan pidana.

\section{Proses Penegakan Tindak Pidana Terhadap Perusahaan yang Tidak Membayar dan Menyetorkan Iuran yang Menjadi Tanggungjawabnya Kepada Badan Penyelenggara Jaminan Sosial}

Penegakan hukum merupakan bagian penting dalam sistem hukum (legal system), dimana hal ini perlu dilakukan dengan berbagai upaya pembinaan secara sistematis dan berkelanjutan. Sebuah ironi ketika hukum dibuat dengan suatu pengorbanan tenaga dan biaya yang amat besar, tetapi sia-sia karena tidak dapat ditegakan.

Oleh karena itu, Undang-Undang Nomor 24 Tahun 2011 tentang Badan Penyelenggara Jaminan Sosial yang merupakan Undang-undang administrasi yang bersanksi pidana sebagai peraturan perundang-undangan pidana di luar KUHP, ${ }^{28}$ telah mengatur 3 (tiga) konsep

28 Inilah yang dimaksud dengan tindak pidana khusus menurut Soedarto, yaitu peraturan-peraturan hukum pidana dalam suatu Undang-undang tersendiri, dimana peraturan-peraturan yang hanya dimaksudkan untuk memberikan sanksi pidana terhadap aturan-aturan salah satu bidang yang dasar dalam ilmu hukum pidana, yaitu tindak pidana, pertanggungjawaban pidana serta pidana atau pemidanaan khususnya terhadap korporasi yang tidak membayar dan menyetorkan iuran yang menjadi tanggungjawabnya kepada Badan Penyelenggara Jaminan Sosial sebagaimana diatur dalam Pasal 55.

Terhadap penegakan tindak pidana atas pelanggaran Pasal 55 Undang-Undang Nomor 24 Tahun 2011 tentang Badan Penyelenggara Jaminan Sosial tersebut, dalam Pasal 11 huruf g dan h telah diatur yang menyatakan : "Dalam melaksanakan tugas sebagaimana dimaksud dalam Pasal 10, BPJS berwenang untuk:

- Huruf (g) : melaporkan Pemberi Kerja kepada instansi yang berwenang mengenai ketidakpatuhannya dalam membayar Iuran atau dalam memenuhi kewajiban lain sesuai dengan ketentuan peraturan perundang-undangan; dan

- Huruf (h) : melakukan kerja sama dengan pihak lain dalam rangka penyelenggaraan program Jaminan Sosial".

Dengan begitu, Badan Penyelenggara Jaminan Sosial Ketenagakerjaan dapat melakukan kerjasama dengan pihak lain dalam penegakan tindak pidana khususnya atas pelanggaran Pasal 55, misalnya dengan pihak Kejaksaan.

Kejaksaan yang memiliki kewenangan dalam bidang Perdata dan Tata Usaha Negara sebagaimana dinyatakan dalam Undang-Undang Nomor 16 Tahun 2004 tentang Kejaksaan. Dengan adanya kewenangan yang diberikan oleh Undangundang kepada Kejaksaan, maka Kejaksaan dapat memberikan bantuan hukum, pertimbangan hukum, pelayanan hukum, tindakan hukum lainnya dan

terletak di luar hukum pidana. Untuk lebih jelas, baca Ardison Asri, Tindak Pidana Khusus; Money Laundering \& Corruption, 2018, hlm. 4. 
penegakan hukum buat Badan Penyelenggara Jaminan Sosial Ketenagakerjaan melalui kerjasama. Melalui kerjasama yang telah dibuat oleh Badan Penyelenggara Jaminan Sosial Ketenagakerjaan, Kejaksaan melalui Surat Kuasa Khusus dapat bertindak selaku Pengacara Negara. Selaku Pengacara Negara yang telah ditunjuk oleh Badan Penyelenggara Jaminan Sosial Ketenagakerjaan, Kejaksaan tentu akan bergerak, baik dalam memberikan bantuan hukum litigasi maupun non litigasi berupa negosiasi, mediasi, bahkan memfasilitasi pertemuan antara perusahaan-perusahaan dengan pihak Badan Penyelenggara Jaminan Sosial Ketenagakerjaan, maupun penegakan hukum dalam hal ini mewakili Badan Penyelenggara Jaminan Sosial Ketenagakerjaan selaku pihak pengugat maupun tergugat di dalam Pengadilan.

Disamping itu, pihak Badan Penyelenggara Jaminan Sosial Ketenagakerjaan bisa juga bekerja sama dengan instansi terkait lainnya, misalnya dengan Dinas Ketenagakerjaan. Hal ini tentu terkait dengan kewenangan yang dimiliki oleh Dinas Ketenagakerjaan yang berkaitan dengan penegakan hukum Pasal 55 Undang-Undang Nomor 24 Tahun 2011 tentang Badan Penyelenggara Jaminan Sosial yang juga dalam UndangUndang Nomor 13 Tahun 2003 tentang Ketenagakerjaan yaitu dalam Pasal 182 Undang-Undang Nomor 13 Tahun 2003, yang menyatakan :

- Pasal 182 ayat (1) : Selain penyidik pejabat Polisi Negara Republik Indonesia, juga kepada pegawai pengawas ketenagakerjaan dapat diberi wewenang khusus sebagai Penyidik Pegawai Negeri Sipil sesuai peraturan perundang-undangan yang berlaku.
Pasal 182 Ayat (2) : Penyidik Pegawai Negeri Sipil sebagaimana dimaksud dalam ayat (1) berwenang :

a. Melakukan pemeriksaan atas kebenaran laporan serta keterangan tentang tindak pidana dibidang ketenagakerjaan;

b. Melakukan pemeriksaan terhadap orang yang diduga melakukan tindak pidana dibidang ketenagakerjaan;

c. Meminta keterangan dan bahan bukti dari orang atau badan hukum sehubungan dengan tindak pidana dibidang ketenagakerjaan;

d. Melakukan pemeriksaan atau penyitaan bahan atau barang bukti dalam perkara tindak pidana di bidang ketenagakerjaan;

e. Melakukan pemeriksaan atas surat dan/atau dokumen lain tentang tindak pidana dibidang ketenagakerjaan;

f. Meminta bantuan tenaga ahli dalam rangka pelaksanaan tugas penyidikan tindak pidana dibidang ketenagakerjaan; dan

g. Menghentikan penyidikan apabila tidak terdapat cukup bukti yang membuktikan tentang adanya tindak pidana dibidang ketenagakerjaan.

Artinya, Dinas Ketenagakerjaan tetap memiliki kewenangan dalam melakukan penyidikan terhadap pelanggaran pidana yang dilakukan oleh korporasi (Pemberi Kerja), akan tetapi tidak memiliki kewenangan dalam melakukan penyidikan terhadap pelanggaran yang dilakukan oleh penyelenggara negara yang mempekerjakan pegawai negeri.

Dengan demikian, Undang-Undang Nomor 24 Tahun 2011 tentang Badan Penyelenggara Jaminan Sosial yang merupakan Undang-undang administrasi 
yang bersanksi pidana sebagai peraturan perundang-undangan pidana di luar KUHP, dalam penegakan tindak pidana terhadap korporasi yang tidak membayar dan menyetorkan iuran yang menjadi tanggungjawabnya kepada Badan Penyelenggara Jaminan Sosial Ketenagakerjaan sebagaimana diatur dalam Pasal 55 dapat melakukan penindakan. Dengan begitu, Hukum (Undang-Undang Nomor 24 Tahun 2011 tentang Badan Penyelenggara Jaminan Sosial) akhirnya bukan hanya menjadi barang mati yang tidak dapat berbuat apaapa bagi masyarakat secara umum dan Pekerja secara khusus dalam pelaksanaan jaminan sosial.

\section{DAFTAR PUSTAKA}

\section{A. Buku-buku}

Ardison Asri, 2018, Tindak Pidana

Khusus; Money Laundering \& Corruption, Diktat Kuliah Tindak Pidana Khusus, Fakultas Hukum Universitas Suryadarma, Jakarta

Chairul Huda, 2006, Dari Tiada Pidana Tanpa Kesalahan Menuju Kepada Tiada Pertanggungjawaban Pidana Tanpa Kesalahan, Cet. Kedua, Kencana, Jakarta

Fokusindo Mandiri, 2014, Sistem Jaminan Sosial Nasional \& Badan Penyelenggara Jaminan Sosial, Bandung

Ishaq, 2009, Dasar-dasar Ilmu Hukum, Sinar Grafika, Jakarta

Lalu Husni, 2010, Hukum Ketenagakerjaan Indonesia, Rajawali Pers, Jakarta
Leden Marpaung, 2005, Asas-TeoriPraktik Hukum Pidana, Cet. Kedua, Sinar Grafika, Jakarta

M. Abdul Kholiq, 2002, Buku Pedoman Kuliah Hukum Pidana, Fakultas Hukum Universitas Islam Indonesia, Yogyakarta

Mahrus Ali, 2015, Asas-Asas Hukum

Pidana Korporasi, PT Raja Grafindo Persada, Jakarta

Moeljatno, 2008, Asas-asas Hukum

Pidana, Cet. Kedelapan, Rineka Cipta, Jakarta

Muladi, 2002, Demokratisasi, Hak Asasi Manusia dan Reformasi Hukum di Indonesia, The Habibie Center, Jakarta

Muladi dan Dwidja Priyatno, 2010, Pertanggungjawaban Pidana

Korporasi, Cet. Kedua, Prenada Media, Jakarta

Pertanggungjawaban Pidana

Korporasi dalam Hukum Pidana, STIH, Bandung

P.A.F Lamintang, 1997, Dasar-dasar Hukum Pidana Indonesia, Cet. Ketiga, PT. Citab Aditya Bakti, Bandung

Remmelink, Hukum Pidana Komentar atas Pasal-pasal Terpenting dari Kitab Undang-undang Hukum Pidana Belanda dan Padanannya dalam Kitab Undang-undang Hukum Pidana Indonesia, Diterjemahkan oleh Tristam Pascal Moeliono, 2003, PT Gramedia Pustaka Utama, Jakarta

Roeslan Saleh, 1983, Tindak Pidana dan Pertanggungjawaban Pidana; Dua Pengertian Dasar dalam Hukum Pidana, Cetakan Ketiga, Aksara Baru, Jakarta 
Sudarto, 1975, Diktat Kuliah Hukum

Pidana Jilid $\boldsymbol{A}-\boldsymbol{B}$, Fakultas

Hukum Univesitas Diponegoro, Semarang

Tongat, 2008, Dasar-dasar Hukum

Pidana Indonesia dalam

Perspektif Pembaharuan, UMM

Press, Malang

\section{B. Peraturan Perundang-undangan}

Undang-Undang Nomor 24 Tahun 2011 tentang Badan Penyelenggara Jaminan Sosial

Undang-Undang Nomor 16 Tahun 2004 tentang Kejaksaan

Undang-Undang Nomor 13 Tahun 2003 tentang Ketenagakerjaan 